\title{
Sylwia Kołos
}

Sylwia Kołos - adiunkt w Zakładzie Filmu i Kultury Audiowizualnej (Katedra Kulturoznawstwa) UMK. Prowadzi także zajęcia z historii filmu w Akademii Muzycznej im. Feliksa Nowowiejskiego w Bydgoszczy (na kierunku reżyseria dźwięku). Autorka książki Nowe kino szekspirowskie. Adaptacje sztuk Williama Szekspira w kinie lat 90-tych XX wieku (2007). Współredaktor tomów: Biografistyka filmowa. Ekranowe interpretacje losów i faktów (2007), Spotkania w przestrzeni idei-słów-obrazów (2012). Obrazy dookoła świata. Postrzeganie i prezentowanie kultur w dobie trans kulturowości (2013), W kręgu jej głównych zainteresowań znajdują się zagadnienia związane z filmowymi adaptacjami literatury, filmami biograficznymi, relacjami między kinem a polityką, filmowymi wizerunkami współczesnych miast Europy i Azji. 


\section{Amélie sprząta toalety, Jiro śni o sushi. Filmowe obrazy „pracy po japońsku" na podstawie filmów Alaina Corneau i Davida Gelba}

DOI: http://dx.doi.org/10.12775/LC.2014.039

„Podziękowanie itadakimasu, jakie w Japonii wypowiada się przed rozpoczęciem jedzenia lub nawet przy przyjmowaniu poczęstunku filiżanką herbaty, może stanowić jeden z kluczy do odczytania kuchni tego kraju. Jej smaki barwy i kompozycje - poruszane czy układane drewnianymi pałeczkami, stanowiącymi godne przedłużenie ludzkich palców - odzwierciedlają prastare filozoficzne podejście, wedle którego pożywienie było postrzegane jako boski dar"1.

Nanako Hamaguchi, Kuchnia japońska.

„Starałam się być spostrzegawczym obserwatorem, ale rychło uświadomiłam sobie, że oddając się mym studiom całym sercem, nie mogę zachować konwencjonalnego dystansu wobec przedmiotu

badań. Całkowicie bowiem pochłonęła mnie nauka, dzięki której miałam stać się gejszą. Znacznie później przyszedł czas na obiektywizm, porządkowanie i analizę doświadczeń”2. Liza Dalby, Gejsza.

\section{Kilka słów o historii}

raca jest w sztuce filmowej tematem równie popularnym jak miłość i zbrodnia. I choć jej dramaturgiczna atrakcyjność wydaje się dużo mniejsza niż miłosne rozterki filmowych bohaterów czy konfrontacja między zbrodniarzem a detektywem, praca towarzyszy rucho-

\footnotetext{
1 N. Hamaguchi, Kuchnia japońska, tłum. A. Polak, Warszawa 2006, s. 6

2 L. Dalby, Gejsza, tłum. E. Pałasz-Rutkowska, Warszawa 2002, s. 10 Liza Dalby jest amerykańską antropolożką specjalizującą się w kulturze japońskiej. Zob. http://www.lizadalby.com/LD/home.html [stan na dzień: 30.01.2013]
} 

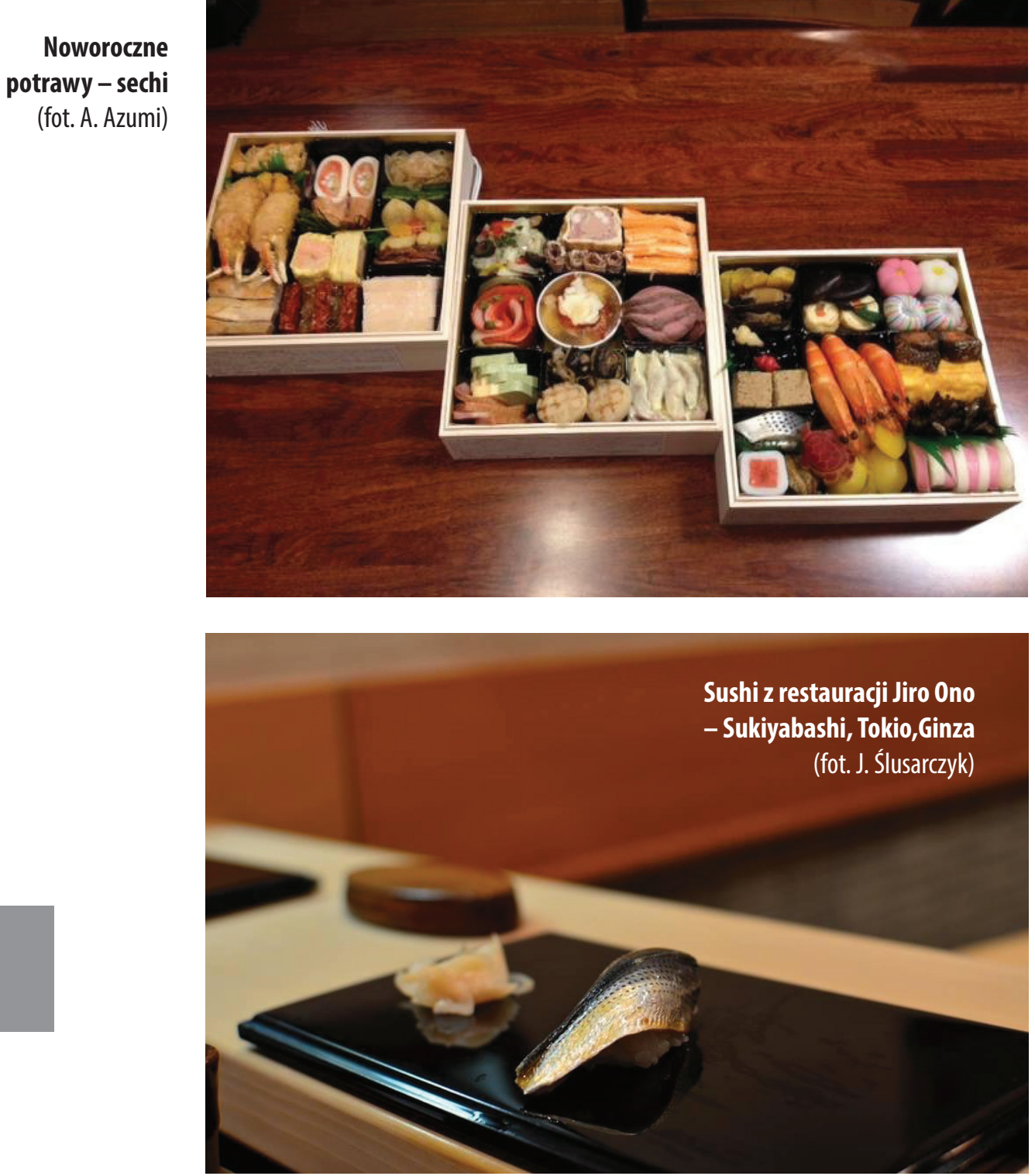

mym obrazom od początku ich istnienia. Jeszcze zanim bracia Lumière zapoczątkowali erę kina, rozumianego jako projekcje ruchomych obrazów dla większej liczby odbiorców jednocześnie, w wytwórni Thomasa Edisona powstawały krótkie filmiki na potrzeby kinetoskopu, czyli jednoosobowego kina ${ }^{3}$. Już w roku 1893 W. K. L. Dickson utrwala na taśmie filmowej krótkie scenki: Blacsmith scene oraz The Barber Shop ukazujące pracę kowali i fry-

${ }^{3}$ „[...] W 1889 jego [Edisona - S.K.] asystent K. L. Dickson, skonstruował kinetofonograf, umożliwiający pokazywanie filmu (wcześniej wynalezionego przez G. Eastmana), zsynchronizowanego z dźwiękiem z płyty gramofonowej. W 1891 Edison przedstawił publicznie kamerę filmową nazwaną kinetografem oraz aparat odbiorczy, tzw. Kinetoskop, pozwalający obserwować film tylko jednej osobie", w: Encyklopedia kina, red. T. Lubelski, Kraków 2003, s. 277, hasło: Edison Thomas Alva, oprac. Ł. Plesnar. 
zjera ${ }^{4}$. W rok później Dickson razem z Williamem Heise realizuje filmik Fire Rescue Scene, który jest pierwszym krokiem do filmowej kariery strażaków i ich profesji. Jej zwieńczeniem, jeszcze w erze kina niemego, będzie oczywiście słynny obraz Edwina Portera $Z \dot{z} y$ cia amerykańskiego strażaka z 1903 roku $^{5}$. Tym samym wytwórnia Edisona wprowadza do filmu temat grup zawodowych. W 1986 Heise razem z Jamesem Whitem realizuje scenę galopady konnej policji pt. Mounted Police Charge. Już po roku sam właściciel wytwórni chce zaprezentować przed kamerą swoją własną pracę. Tak powstaje scena o znamiennym tytule Mr. Edison at Work in his Chemical Laboratory. W 1908 roku Edison kręci niezwykły film zatytułowany The Gay Shoe Clerk, który, podobnie jak kilka lat wcześniej uczynił to obraz $Z \dot{z} y c i a$ amerykańskiego strażaka, przenosi filmowe obrazy pracy na nieco inny poziom, rzec można - bardzo współczesny. Praca staje się tematem filmów fabularnych, okazuje się bowiem, że jej wykonywanie może generować interesujące rozwiązania dramaturgiczne. W jednej z najsłynniejszych filmowych strażackich opowieści Porter opowiada historię, uwięzionej w płonącym domu matki z dzieckiem, z dwóch różnych punktów widzenia. W The Gay Shoe Clerk prozaiczne kupowanie butów staje się zarzewiem erotycznej interakcji między sprzedawcą a klientką. Ukoronowaniem transferu tematu pracy na grunt filmu fabularnego są bez wątpienia dwa arcydzieła Charlesa Chaplina - pierwszy jeszcze z czasów kina niemego - Brzdac (The Kid, 1921) oraz Dzisiejsze czasy (Modern Times, 1936).

$\mathrm{Na}$ starym kontynencie pierwsi filmowcy też nie gardzą tematem pracy. W pewnym sensie historia kina w Europie zaczyna się, gdy dwaj bracia utrwalają na taśmie robotników wychodzących z fabryki po skończonej pracy. Warto też zastanowić się, o czym w istocie traktuje pierwsza filmowa komedia braci Lumière Polewacz polany (L'Arroseur arrosé, 1895)? Jest to krótka historia o człowieku, któremu ktoś przerywa wykonywanie pracy. W tym kontekście bardzo interesująca wydaje się płyta DVD zatytułowana The Lumière Brothers' First Films ${ }^{6}$. Otóż jedna z części tej edycji zatytułowana jest France at Work i dowodzi, jak wiele czasu - i taśmy filmowej - przeznaczali Francuzi na filmowanie klasy pracującej, rolników oraz - co wydaje się szczególnie ważne - pracujących kobiet. W odróżnieniu od realizatorów z wytwórni Edisona Francuzi nie szukają wśród różnych grup zawodowych, fabryk i pól uprawnych tematów filmów fabularnych (może z wyjątkiem Polewacza polanego), ale wykorzystują temat i kamerę do pierwszych filmowych prób analizy społeczeństwa, w którym żyją, budując tym samym silne rudymenty społecznego dokumentu.

Dużo bardziej radykalne społecznie przesłanie będą miały filmy dokumentalne ze szkoły Johna Griersona, dla której praca i klasa pracująca stanowiła temat fundamentalny, o czym świadczą tytuły filmów: Poławiacze śledzi Griersona (Drifters, 1929) czy Nocna poczta Basila Wrigtha (Night Mail, 1936). Tę tradycję postanowili kontynuować w Wielkiej Brytanii twórcy Free Cinema - powojenni epigoni Griersonowskiego dokumentu. A najbardziej reprezentatywnym przykładem kontynuacji myśli dokumentalistów sprzed II wojny światowej do dziś pozostaje obraz zatytułowany Hale targowe w Londynie Lindseya An-

${ }^{4}$ Scenkę The Barber Shop Dickson zrealizował razem z Williamem Heise. Warto przy tej okazji wspomnieć o jeszcze jednej scenie utrwalonej na tasmie filmowej przez obu realizatorów. Choć wśród wczesnych filmów zrealizowanych w wytwórni Edisona nie znajdziemy takich, które ukazują pracowitych Japończyków, sam temat kultury japońskiej pojawia się w Edisonowskich kinetoskopach już w 1894 r., kiedy to Dickson i Heise rejestrują krótką, bo zaledwie 20-sekundową, scenę pt. Imperial Japanese Dance, przedstawiającą trzy tańczące, ubrane w tradycyjnie kimona Japonki.

${ }^{5}$ Edwin Porter zrealizował ten film przy współpracy George’a Fleminga i Jamesa White'a.

6 Płyta wydana przez "Lumière Brothers' Association”, red. Thierry Fermaux, Institut Lumière oraz Archives du Film du Centre National de la Cinématographie. 
dersona (Every Day Except Christmas, 1957) przedstawiający pracowników hal targowych Covent Garden 7 . Kino brytyjskie, od pierwszych wystąpień Młodych Gniewnych do dnia dzisiejszego, w sposób szczególny traktuje temat pracy (bądź jej braku), kapitalizmu, postthatcherowskich „skrzywdzonych”, czego dowodem jest cała grupa filmów, które zwykliśmy nazywać - brytyjskim kinem społecznym.

\section{Japończycy i praca}

Jacy są Japończycy? Pracowici - to jeden z tych przymiotników, które najszybciej przychodzą nam na myśl, kiedy mamy opisać mieszkańców Kraju Kwitnącej Wiśni. Praca, ściślej - szacunek dla pracy, utożsamienie się z miejscem pracy, firmą, korporacją, to integralna część japońskiej kultury ${ }^{8}$ I nie ma specjalnego znaczenie, czy jest się prezesem wielkiego przedsiębiorstwa z siedzibą w Tokio, czy operatorem wózków widłowych na japońskiej prowincji. Etos pracy definiuje japońskie społeczeństwo, jak żadne inne.

Przez całe powojenne dziesięciolecia pracę i awans zawodowy w Japonii warunkowały ściśle określone zasady, które jednak po roku 1990, w obliczu kryzysu i recesji musiały ulec zmianie.

Przez długi czas w firmach tego kraju funkcjonowały dwa uzupełniające się systemy. Dożywotnie zatrudnienie, które gwarantowało pracę w danej firmie aż do emerytury, oraz system pierwszeństwa awansu według stażu pracy. Oba miały na celu wytworzenie silnej więzi między przedsiębiorstwem i jego pracownikami?

Ostatecznie także globalizacja wymusiła ma Japończykach pewna reformę zasad zatrudnienia i funkcjonowania w korporacji.

Dzisiaj system awansu i płac zbliżony jest do europejskiego, a także sami Japończycy częściej i chętniej zmieniają miejsca pracy. Mimo tych przemian i słabszej kondycji japońska firma dalej wyróżnia się na tle świata swoją specyficzną kulturą pracy, a miejsce pracy gra bardzo ważną role w życiu zwykłego Japończyka ${ }^{10}$.

\section{Jiro i Amélie}

Wbrew pozorom filmowa refleksja na temat pracy nie skończyła się na filmach Charliego Chaplina czy nawet na społecznym kinie brytyjskim. Temat ten funkcjonuje w filmie przez cały czas, choć obecnie najczęściej jest eksploatowany przez kulturę serialową. Jednak jej specyfika sprawia, że oglądając seriale myślimy raczej o grupach zawodowych, np.: lekarzach, prawnikach i politykach, rzadziej o wykonywanej przez nich pracy, nawet wtedy,

\footnotetext{
${ }^{7}$ W polskim piśmiennictwie film Andersona funkcjonuje pod dwoma polskimi tytułami: Hale targowe w Londynie oraz Codziennie z wyjątkiem Bożego Narodzenia.

${ }_{8}$ Zob. K. Grosiak, W japońskiej firmie gorzej niż w wojsku http://manager.money.pl/news/artykul/w;japonskiej; firmie;gorzej;niz;w;wojsku,209,0,424401.html [stan na dzień: 19.03.2013].

9 Ibidem.

10 Ibidem.
} 
gdy analizując fenomen kultury serialowej, używamy takich określeń jak 'serial medyczny' (a nie np.: lekarski). Opisujemy zatem zawody i miejsca, w których rozgrywa się historia, a nie charakter pracy bohaterów. Jest to zupełnie naturalny sposób odbioru uwarunkowany określonymi scenariuszowymi paradygmatami, które zazwyczaj przenoszą najważniejsze dramaturgiczne akcenty na życie osobiste postaci, ich sercowe rozterki, nawet jeśli dziewięćdziesiąt procent akcji filmu (odcinka) rozgrywa się w szpitalu lub w budynku sądu.

Na tym tle dokumentalny obraz Davida Gelba Jiro śni o sushi (Jiro Dreams of Sushi, 2011) oraz filmowa adaptacja powieści Amélie Nothomb $Z$ pokora i uniżeniem ${ }^{11}$, wyreżyserowana przez Alaina Corneau ${ }^{12}$, prezentują się wyjątkowo i oryginalnie. Są to bowiem filmy przede wszystkim o pracy. I co znamienne - obydwa dotyczą Japonii. Spójnej tematycznie narracji nie zakłócają tu w zasadzie żadne wątki poboczne. Informacje niezwiązane z pracą są w obu przypadkach nader oszczędne.

Kiedy Gelb realizował swój dokument, bohater jego filmu miał 85 lat.

Jiro Ono jest właścicielem najmniejszej restauracji świata, która otrzymała trzy gwiazdki w prestiżowym rankingu Michelina. To legendarne miejsce w samym sercu Tokio, gdzie serwowane jest wyłącznie sushi. Za najwyższą jakość płaci się tu astronomiczne ceny, a mimo to na rezerwacje stolika trzeba czekać wiele tygodni. Ale Jiro Ono poświęcił swojej restauracji i poszukiwaniu doskonałego smaku całe życie ${ }^{13}$.

Jiro Ono, zdobywca Świętego Grala restauratorów - trzech gwiazdek Michelina - jest legendą, jedną z tych postaci, które w nas, nie-Azjatach, utrwalają mit Kraju Kwitnącej Wiśni. Jiro i jego mały świat to z naszego, europejskiego punktu widzenia kwintesencja ,japońskości”.

Amélie to zupełnie inny przypadek. Przede wszystkim historia bohaterki - zarówno literackiej, jak i filmowej - jest także mocno osadzona w rzeczywistości. Podobnie jak w wypadku Jiro śni o sushi, mamy tu do czynienia z opowieścią biograficzną, choć nie dokumentalną. Amélie Nothomb, belgijska pisarka, córka dyplomatów urodziła się w Kobe w roku 1967. Do piątego roku życia mieszkała w Japonii. Po latach wraca tam na staż w firmie, w której zatrudnia się jako tłumaczka. Powieść Z pokorą i uniżeniem oraz jej filmowa, bardzo wierna, adaptacja są zapisem tego niezwykłego zawodowego doświadczenia.

Fakt, że w przypadku obu filmów odbiorca zostaje skonfrontowany z prawdziwymi wydarzeniami (choć zaprezentowanymi w różnych filmowych rodzajach), wydaje się bardzo istotny. Podobnie, jak narodowość ich twórców i bohaterki drugiego z nich. Warto zatem przyjrzeć się obu obrazom w kontekście pozycjonizmu ${ }^{14}$. I choć są to artystyczne refleksje

11 Swoją światową premierę książka miała w roku 1999. W Polsce została wydana w roku 2000, w tłumaczeniu Barbary Grzegorzewskiej.

12 W Polsce film był wyświetlany pod tytułem Bojaźń i drżenie (2003). O dyskusyjnym tłumaczeniu tytuły filmu na język polski pisałam w tekście Za oknem Tokio. Obraz Japonii w filmach reżyserów spoza Azji - na wybranych przykładach [w:] Obrazy dookoła świata. Postrzeganie i prezentowanie kultur w dobie trans kulturowości red. J. Bielska-Krawczyk, S. Kołos, M. Mateja, Toruń 2013, s. 322, cytuję: „Tytuł jest w przypadku filmu nieco mylący, sugeruje bowiem związek z dziełem Sørena Kierkegaarda Bojaźń i drżenie. Choroba na śmierć. To oczywiście mylny trop. Film powstał na podstawie autobiograficznej powieści Amélie Nothomb Stupeur et tremblements, której polskie tłumaczenie brzmi Z pokorq i uniżeniem i doskonale oddaje charakter zarówno książki, jak i jej filmowej, bardzo wiernej, adaptacji".

${ }_{13}$ Materiały promocyjne "Gutek Film” http://www.gutekfilm.pl/nadvd/film/28204,,pl,,,Jiro-ni-o-sushi. html [stan na dzień: 29.04.2013).

${ }_{14}$ Mariusz Czepczyński pisze: „Podstawowa koncepcja pozycjonizmu opiera się na relacjach między obiektem badań a rezultatem. Wg lana Cooka (2005) w „tradycyjnej” nauce opierającej się na scjentystycznych inter- 
dotyczące konkretnego zjawiska, a nie typowy materiał badawczy (wypowiedzi badaczy i wyniki ich badań), wydaje się, że ceniona, zwłaszcza przez geografów kultury i socjologów, metodologia może okazać się istotna dla filmowych historii Jiro i Amélie.

\section{David Gelb przedstawia Jiro Ono}

David Gelb, absolwent studiów filmowych na Uniwersytecie Karoliny Południowej, pokochał smak sushi jeszcze jako nastolatek, kiedy jego ojciec Peter - dyrektor Metropolitan Opera - zabrał go w podróż służbową do Japonii ${ }^{15}$. Jiro śmi o sushi nie jest jednak pierwszym filmem Gelba o japońskiej sztuce kulinarnej. W roku 2009 Gelb zrealizował krótki pięciominutowy film/clip ukazujący jednego z najsłynniejszych sushimasterów w Stanach Zjednoczonych. Nozawa mógł początkowo zostać bohaterem filmu pełnometrażowego, jednak spotkanie z Jiro Ono i jego synem zmieniło plany reżysera ${ }^{16}$. Od tej pory „miał to być film nie tylko o sushi; film zmienił się w opowieść o rodzinie, sukcesji i filozofii ciężkiej pracy"17. I nie da się ukryć, że wszystko, co zdarzyło się - i nadal się dzieje - w życiu Jiro jest konsekwencją owej filozofii, którą stara się zgłębić zafascynowany sztuką sushi i jej największym mistrzem przybysz z innego kraju. Autor filmu nazywa swojego bohatera „żywą legendą sushi” lub „niekwestionowanym Bogiem sushi” ${ }^{18} \mathrm{i}$ ani przez chwilę nie ukrywa zachwytu dla jego umiejętności. Jednocześnie udowadnia, że świat prawdziwego sushi to Japonia, a filmu o tej tematyce nie da się zrealizować nigdzie indziej.

Życiowe credo Jiro Ono brzmi: „Decydując się na to, co będziesz robił w życiu, poświęć się pracy bez reszty. Kochaj swoją pracę. Nigdy na nią nie narzekaj. Całe życie doskonal umiejętności. Tylko wtedy osiągniesz sukces i tylko wtedy będziesz budzić szacunek"19. To postawa, która cechuje każdego shokunina ${ }^{20}$. To rudymenty filozofii pracy japońskiego rzemieślnika.

pretacjach dominowały jednokierunkowe lub „obiektywne związki badanego obiektu i rezultatu badań: obiekt $\rightarrow$ "tekst". Post-modernistyczne i humanistyczne podejścia zakładają natomiast wielopoziomowe i „subiektywne" relacje o charakterze interakcyjnym, typowym dla badań społecznych. Obiekt badawczy nie tylko wpływa na badacza, ale także badacz często wpływa na obiekt; podobnie jak tekst czy odbiorcy oddziałują zarówno na badacza, jak i na sam obiekt: obiekt $\leftrightarrow$ naukowiec $\leftrightarrow$ "tekst" $\leftrightarrow$ odbiorcy. Pozycjonizm zakłada istotność społecznego kontekstu badań i badacza oraz uwypukla rolę jego własnych preferencji, doświadczeń, wierzeń, wykształcenia i ulokowanie w strukturze nauki w procesie badawczym. Badacz ten jest świadomy własnej pozycji i ograniczeń poznawczych. Pozycjonizm i sytucjonizm starają się w naukowy sposób określić odwieczny problem relacji podmiotu i przedmiotu badań, od którego nauka chce, ale nie może odejść. Jednokierunkowa "obiektywna" relacja przedmiot - podmiot badawczy sprawdzała się w znacznym stopniu w naukach ścisłych, zaś w naukach społecznych tworzyła wyidealizowany obraz wszechwiedzącego naukowca, pozbawionego wyboru, historii i odczuć. W przeważającej większości nauk społecznych, w tym geografii społecznej, to poszczególni badacze sami subiektywnie odbierają zarówno interesujące i ważne dla nich tematy badawcze, jak i metody, które uważają za najlepsze czy prawdziwe, zgodnie ze swoją „pozycją” w systemie nauki, oczekiwaniami i preferencjami metodologicznymi". Zob. M. Czepczyński, Podejścia badawcze w nowej geografii kultury, [w:] Geografia a przemiany współczesnego świata, red. W. Maik, K. Rembowska, A. Suliborski, Bydgoszcz 2007, s. $203-211$.

15 Zob. Wywiad Brandona Harrisa z Davidem Gelbem, „Filmmaker Magazine”, Mar 7, 2012; wywiad również dostępny w całości na http://filmmakermagazine.com/42255-david-gelb-jiro-dreams-of-sushi/ [stan na dzień: 30.04.2012]

16 Ibidem.

17 Ibidem. Początkowo Gelb chciał też zrealizować film o sztuce sushi, prezentując i konfrontując ze sobą historie kilku sushimasterów.

18 Ibidem.

19 Scieżka dialogowa filmu.

20 Postawa shokunina ma swoją wielowiekową tradycję: „Japończycy uważają, że w okresie Edo (1603-1867) ukonstytuował się system kastowy, w którym rzemieślnicy uważani byli za klasę wyższą niż kupcy - 
Bycie shokuninem (rzemieślnikiem) w Japonii oznacza, między innymi powtarzanie każdego ranka tych samych czynności, które wykonywało się wczoraj i przedwczoraj. Przeszłość i przyszłość stapiają się w jedno, tworząc wrażenie niekończącej się teraźniejszości, gdzie rzemieślnik i jego rzemiosło są spleceni razem, tworząc coś na kształt konwersacji, z której wszyscy inni są wyłączenia. Jest to związek silniejszy niż rodzina. To rodzaj obsesyjnego poświęcenia, które swoją siłą jest w stanie pokonać każdy inny związek emocjonalny. Shokunin nie jest zainteresowany poszukiwaniem szczęścia osobistego, gdyż wie, że jego rzemiosło jutro będzie lepsze, niż było wczoraj $[\ldots]$. Prawdziwy shokunin zanurza się w jeziorze swojego zawodu i nigdy z niego nie wychodzi, aż wszystkie emocje i obawy znikają, stają się nieistotne. Japończycy mają wrodzone przekonanie, że tak właśnie powinno być i analizowanie tego stanu rzeczy, nie ma sensu ${ }^{21}$.

Jiro to shokunin. Ten stan rzeczy nie wymaga dodatkowego komentarza. Możemy również domniemywać, że dotyczy to też jego synów. Poznajemy ich w momencie, kiedy osiągnęli już ten stopień zawodowego wtajemniczenia. W tym kontekście znacząca wydaje się opowieść starszego ucznia Jiro - Nakazawy. Historia chłopaka namaszczonego na shokunina przez samego Jiro, jest doskonałą egzemplifikacją tego procesu. Nakazawa terminował u Jiro już dziesięć lat, kiedy mistrz pozwolił mu zrobić sushi z jajkiem. Choć uczeń był przekonany, że ma ku temu wystarczające umiejętności, musiał przyrządzić omlet aż dwieście razy, zanim szef zaakceptował jego smak i - co najważniejsze - nazwał Nakazawę shokuninem. Scena, w której bohater przekłada na płytę wysmażony omlet, jest więc czymś więcej niż zwykłą czynnością wykonywaną w restauracyjnej kuchni. To niemal czynność wieńcząca rytuał przejścia ${ }^{22}$.

Jednak reżyser nie zamierzał robić filmu o rzemieślniku. Chciał zrobić film o artyście i pracy, która stała się sztuką najwyższej próby. Gelb przyznaje „Pochodzę z rodziny, która ceni sztukę, jedzenie, muzykę - zawsze celebrujemy kulturę"23. Twierdzi, że nawet wspomnienia $\mathrm{z}$ dzieciństwa pełne są wykwintnych potraw jadanych zarówno w restauracjach, jak i przy domowym stole ${ }^{24}$. „Uznanie dla dobrego jedzenia mam więc wrodzone, ale doświadczenie z Jiro mną wstrząsnęło" ${ }^{25}$, mówi autor filmu. Stwierdzenie, że to pochodzenie, dom i wychowanie wpłynęly na artystyczne wybory i decyzje reżysera, nie jest chyba przesadą. Pozycja, z jakiej percypuje rzeczywistość, to pozycja konesera, która każe mu do historii shokunina dopisać jej drugą część - historię artysty. Gelb zdaje się mówić: droga japońskiego 'rzemieślnika doskonałego' jest drogą ku mistrzostwu i prawdziwej sztuce. Shokunin staje się artystą.

Opowieść o artyście wymaga odpowiedniej oprawy. Nawet w filmie dokumentalnym. Mówiąc może nieco banalnie, obraz Gelba ogląda się z dużą przyjemnością. Sceny ukazujące przyrządzanie sushi są niemal poetyckie. Wyrazista formula audialna i wizualna tych fragmentów podkreśla artyzm działań bohatera. Najlepszego na świecie sushi nie można wszak robić i pokazywać ot tak, zwyczajnie. Najlepsze na świecie sushi najpierw - wzorem Jiro - trzeba

byli szanowani i chronieni jako strażnicy tradycji, zaś nieco pogardzani kupcy mieli opinię dorobkiewiczów", w: Kaori Shoji, Dedication on a plate in 'Jiro Dreams of Sushi', "The Japan Times", Feb 1, 2013. Artykuł dostępny na http://www.japantimes.co.jp/culture/2013/02/01/films/dedication-on-a-plate-in-jiro-dreams-of-sushi/\#.UZ-F3 kpftUk [stan na dzień: 30.04.2013].

21 Ibidem.

22 Por. Wywiad Brandona Harrisa z Davidem Gelbem, op. cit.

23 Ibidem

24 Zob. ibidem.

25 Ibidem. Należy jednak dodać, że Jiro Ono nie był początkowo entuzjastą projektu Gelba. Więcej, kategorycznie odrzucił pierwszą propozycję młodego reżysera. 
wyśnić. Następnie jego przyrządzanie i serwowanie zmienić w prawdziwy kulinarny koncert ${ }^{26}$, podkreślając jego jakość wysublimowaną formułą audiowizualną. Choć należy podkreślić, że nie jest to w filmie dokumentalnym nowa jakość ${ }^{27}$. Chodzi nie tylko o wykorzystanie przez twórcę tego rodzaju filmowej wypowiedzi, lecz także o konkretne rozwiązania formalne. I tu - pozwalając sobie na nieco recenzencki ton - trzeba stwierdzić, że Gelb i jego współpracownicy trochę rozczarowują. Jiro śni o sushi może wydawać się osobom znających nieco lepiej kulturę filmową obrazem nieco wtórnym - wtórnym wobec Koyaanisqatsi (1983) Godfreya Reggio. Mimo iż tematycznie obydwie produkcje bardzo się od siebie różnią, formalnie w niektórych fragmentach - są wręcz identyczne ${ }^{28}$. O filmie Reggio czytamy na przykład:

Film zrealizowany został techniką kolażu ujęć i scen, nakręconych przez operatora Rona Fricke'a, bądź wykorzystujących dokumentalne zdjęcia. [... ] Poddany rytmowi muzyki Philipa Glassa obraz skupia się wokół rzeczy najprostszych i przywołuje najbardziej podstawowy aspekt kina - pokazuje, jak bardzo fascynujące są chmury, rośliny, kamienie, woda. Dzięki nieskomplikowanym technikom, jak przyspieszone i zwolnione klatki, odkrywa na nowo kształty, kolory i ruch rzeczy tak powszechnych i naturalnych, że stały się wręcz niezauważalne ${ }^{29}$.

Po wprowadzeniu do powyższego fragmentu zmian dotyczących treści filmu, można tym samymi słowami opisać film Jiro śni o sushi, np.: poddany rytmowi muzyki Philipa Glassa obraza skupia się wokół rzeczy najprostszych i przywołuje najbardziej podstawowy aspekt kina - pokazuje jak bardzo fascynujące są dłonie formujące ryż na sushi, kapiąca woda, wyrabianie ciasta na omlet, czyszczenie ryby, krojenie tuńczyka. Dzięki nieskomplikowanym technikom, jak przyspieszone i zwolnione klatki, odkrywa na nowo kolory i ruch rzeczy tak powszechnych i naturalnych, że stały się wręcz niezauważalne. Obaj reżyserzy celebrują niezwykłość prostoty, w identyczny niemal sposób i przy współpracy tego samego kompozytora ${ }^{30}$.

Jednak w przedstawionej przez Gelba historii równie ważne (nawet zaskakujące) jest to, czego i kogo na ekranie nie widać. Świat Jiro - mistrza sushi - to „świat bez kobiet”. Mimo iż reżyser reklamował swój obraz jako opowieść także o rodzinie i podkreślał jej bardzo osobisty charakter ${ }^{31}$, niezwykle istotny dla emocjonalnego waloru filmu ${ }^{32}$, nie ma w nim żony Jiro, matki jego dwóch synów. Teraźniejszość życia osobistego i rodzinnego

${ }^{26}$ Określenie koncert w odniesieniu do potraw serwowanych przez Jiro Ono pojawia się kilkakrotnie w filmie Gelba. Używa go między innymi Masuhiro Yamamoto - słynny japoński krytyk kulinarny.

${ }_{27}$ W polskim dokumencie pojęcie "dokument poetycki” zostało zastąpione określeniem „dokument kreacyjny". Mirosław Przylipiak pisze: „Jest to właściwie osobny gatunek charakteryzujący się wykorzystywaniem wyrazistych środków ekspresji wizualnej i dźwiękowej, przez długi czas zarezerwowanych jedynie dla kina fabularnego czy eksperymentalnego". Zob. M. Przylipiak, hasło: dokument kreacyjny, w: Encyklopedia kina, red. T. Lubelski, Kraków 2003, s. 252.

28 Porównanie obu filmów może początkowo dziwić, ponieważ obraz G. Reggio to filmowa impresja z silnym akcentem ekologicznym. „Koyaanisqatsi oznaczające w języku Indian Hopi «życie w stanie nieznośnego rozchwiania», to swoiste połączenie filmu dokumentalnego z eksperymentem i filmem dydaktycznym. Reggio, który przez długi czas był nauczycielem, a zajmuje się również socjologią, nadał swojemu filmowi wydźwięk popularnonaukowy - chciał pokazać naszą planetę jako zjawisko niezwykłe, wręcz nieznane, poddane ciągłej przemianie, tworzeniu i destrukcji", [w:] B. Kosecka, A. Piotrowska, W. Kocołowski, Panorama kina najnowszego 1980-1995, Kraków 1998, s.78. Jednak koncepcja obrazu i współpraca z kompozytorem Philipem Glassem wskazuje jednoznacznie na źródło inspiracji Davida Gelba.

${ }^{29}$ Ibidem.

30 Wtórność pracy Philipa Glassa wydaje się jeszcze głębsza. W filmie Jiro śni o sushi wykorzystał bowiem muzykę, którą skomponował do filmu Godziny (2002) Stephena Daldry'ego.

31 Zob. Wywiad Brandona Harrisa z Davidem Gelbem, op. cit.

32 Ibidem. 
Jiro w filmie ogranicza się do jego synów ${ }^{33}$, przeszłość do opowieści o rodzicach, czasach szkolnych i początkach pracy. Synowie mówią o matce tylko jeden raz, podobnie Jiro, kiedy wspomina dzieciństwo Yoshikazu (starszy syn) i Takashiego (młodszy syn), dla których był $\mathrm{w}$ istocie kimś obcym, wracał bowiem z pracy do domu tylko w niedzielę. O życiu prywatnym dorosłych synów ${ }^{34}$ Jiro też niczego się nie dowiadujemy. Jedynym wyjątkiem jest informacja o pewnej fascynacji Yoshikazu - granatowym audi, które osiąga prędkość $300 \mathrm{~km} / \mathrm{h}$. Doskonale natomiast wiemy, jak pracują - ze świadomością, że nic innego się nie liczy: jedynie sushi i nazwisko Ono, będące obecnie światową marką.

Film Gelba to opowieść o pracujących mężczyznach. Kobiet nie ma w niej w ogóle, z wyjątkiem dwóch klientek w restauracji Jiro, zachwycających się smakiem sushi. Co ciekawe, sushi dla kobiet szef kuchni zawsze przyrządza mniejsze, do czego przyznaje się przed gośćmi. Widzowie, zachwyceni tym, co do tej pory widzieli, skłonni są i tę stosowaną przez Jiro zasadę uznać za kolejny element kulinarnej filozofii bohatera.

Kiedy poznaliśmy już Jiro Ono, jego synów, uczniów, dostawcę ryżu i sprzedawców ryb, Masuhiro Yamamoto - krytyk kulinarny - zaskakuje nas niezwykłą informacją: w czasie, kiedy ludzie z Michelina sprawdzali restaurację Jiro - czego zwieńczeniem było przyznanie nu słynnych trzech Michelinowskich gwiazdek - sam mistrz ani razu nie zrobił sushi. Przygotowywał je wówczas jedynie Yoshikazu, jego starszy syn! Zaskakująca, ale i wspaniała pointa, godna najlepiej skomponowanej fabuły. Każe nam bowiem raz jeszcze spojrzeć na bohatera/bohaterów (?) filmu i sukcesu Sukiyabashi - najmniejszej restauracji świata. Pod koniec filmu już wiemy, że musimy obejrzeć go raz jeszcze. Trzeba spojrzeć na tę filmową refleksję na temat „pracy po japońsku” z perspektywy Yoshikazu, który może nie śni o sushi, ale robi je najlepiej, jak potrafi - po mistrzowsku. I w pewnym sensie anonimowo. Dopóki Jiro Ono jest właścicielem restauracji, dopóty sława i gwiazdki Michelina należą tylko do Jiro, a Yoshikazu pozostaje jedynie sukcesorem. Nagle film o kulinariach i japońskiej filozofii pracy zmienia się w opowieść o ojcu i synu. A może przede wszystkim o synu ... ? ${ }^{35}$

\section{Amélie przedstawia japońską korporację}

Mimo iż głównym tematem filmu Bojaźń i drżenia jest także praca w Japonii, trudno porównywać z sobą obraz Gelba i Corneau. Nie tylko ze względu na ich odmienność rodzajową: Jiro śni o sushi to dokument, Bojaźń i drżenie - film fabularny, adaptacja powieści Amélie Nothomb $Z$ pokora i uniżeniem. Analiza porównawcza nie jest zresztą celem tego artykułu. Dużo ciekawsza wydaje się różnorodność refleksji na ten sam temat. Opowieść Amélie - „pani Zemsty”36, jest zupełnie czymś innym, niż historia przedstawiona przez Gelba - zafascynowanego swoim bohaterem i jego pracą. Zanim jeszcze Corneau podjął się przeniesienia utworu Nothomb na

33 Uściślając - jednego z synów, starszego, który pracuje razem z ojcem. Młodszy syn Jiro zdecydował się otworzyć własną restaurację, narażając się tym samym na gniew ojca. Jiro przyznaje nawet, że w dniu otwarcia restauracji Takashiego powiedział do syna "Od dziś nie masz domu". Choć bohater filmu przed kamerą filmową stara się historię swojego konfliktu z młodszym synem podsumować żartem i uśmiechem, widz i tak zdaje sobie sprawę z powagi tej sytuacji.

${ }^{34}$ Starszy Yoshikazu w chwili realizacji filmu miał już pięćdziesiąt lat.

35 Nie chcę używać sformułowania - „o synowskim poświęceniu", bo brzmi to zbyt telenowelowo i pretensjonalnie, choć prawdziwie.

${ }_{36}$ Pani Zemsta to tytuł południowokoreańskiego filmu Chan-wookParka, z roku 2005. Tytuł został przeze mnie wykorzystany jedynie jako element charakterystyki bohaterki-narratorki. 
ekran, wielu czytelników i krytyków uznało jej powieść za literacką zemstę na Japonii. Sam reżyser zaś pozostał bardzo wierny literackiemu pierwowzorowi. Charakter adaptacji skłania odbiorcę do uznania nadrzędności autorskiego punktu widzenia autorki książki, który poddany intersemiotycznej transpozycji - organizuje narrację filmową. W związku z tym, że $Z$ pokora $i$ uniżeniem to powieść autobiograficzna, obraz Corneau można traktować jako film oparty na faktach. Informacja, że film ma źródło w rzeczywistości wydaje się bardzo znaczący dla jego odbioru. Punkt widzenia Amélie Nothomb jako autorki książki i bohaterki - najpierw utworu literackiego, a następnie także adaptacji - jest instancją nadrzędną dla filmowego diegesis. To istotne także dla wspomnianego wcześniej kontekstu pozycjonistycznego. Historia Amélie, która pracuje w japońskiej korporacji, jest interesująca dlatego właśnie, że jest autobiograficzną opowieścią o Europejce w Kraju Kwitnącej Wiśni. David Gelb jako reżyser swojego filmu nie żył w świecie Jiro, był jedynie jego obserwatorem zafascynowanym tym, co widzi. Amélie, Belgijka z pochodzenia, opowiada o swoim życiu i pracy w Japonii i pozwala sobie - jak nazwała to Izabela Przylipiak - mały akt zemsty ${ }^{37}$.

Amélie decydując się na pracę w japońskiej korporacji była optymistką. Znała bowiem język i miała wrażenie, że całkiem dobrze zna także ten kraj. Praca tłumaczki wydawała się zatem dla niej stworzona. Nic bardziej błędnego. Znajomość japońskiego urodzonej w Japonii Belgijki okazuje się niewystarczająca, współpracownicy okrutni i fałszywi, a sytuacje, z jakimi bohaterka musi się zmagać tak absurdalne, że aż godne gombrowiczowskiego świata $^{38}$. Czytelnika i widza zaskakuje już sam początek zawodowej „kariery” bohaterki, która w korporacji w kraju, gdzie etos pracy jest sprawą absolutnie fundamentalną, nie ma w zasadzie co robić. „Choć zatrudniono ją jako tłumaczkę dziewczyna snuje się po korytarzach bez zajęcia, a gdy ucieknie się do podstępu, żeby się wykazać, zostanie za to surowo ukarana" ${ }^{\text {" }}$. Upokarzana, poniżana i zdegradowana do funkcji babci klozetowej (pomimo tego, że i w tej przestrzeni biurowej jej praca zdaje się zbędna) Amélie robi wszystko, by, jak nakazują japońskie standardy, zachować twarz do końca kontraktu ${ }^{40}$. „Przez siedem miesięcy zamiast wykorzystywać umiejętności nabyte podczas studiów, sprząta toalety. Co jest tym bardziej absurdalne, że tę pracę wykonują również sprzątaczki” ${ }^{41}$ - pisze Mariusz Cieślik i dodaje:

Dla Japończyków ta degradacja nie jest w zasadzie niczym dziwnym, choć w pewnym momencie korzystanie z toalety staje się dla pracowników firmy czymś w rodzaju demonstracji politycznej - wyznacznikiem stosunku do cudzoziemców. Jeśli bowiem wierzyć Nothomb, Japończycy są głęboko przekonani o własnej kulturowej i intelektualnej wyższości nad Europejczykami ${ }^{42}$.

Zatem w zaproponowaną przez pisarkę i reżysera refleksję na temat pracy „po japońsku” wpisany został niezwykle istotny problem: Europejczyk (obcy) w Japonii i japońskiej firmie. Kontekst „obcości” w tym przypadku nabiera dodatkowego znaczenia, bowiem „obcą” jest kobieta. Amélie jest obca i inna, co w filmie wybrzmiewa silniej niż w książce. Obraz filmowy najprostszymi środkami podkreśla inność głównej bohaterki. Corneau ograniczył filmową przestrzeń do pomieszczeń biurowych (z wyjątkiem krótkich retrospektywnych

\footnotetext{
37 I. Przylipiak, Z pokorq i uniżeniem „Gazeta Wyborcza”, 4.05.2001.

38 Ibidem.

39 Ibidem.

40 Por. Ed Gonzalez, Fear and Tremblind, "Slant Magazine", Nov 9/2004.

${ }^{41}$ M. Cieślik, Z pokorq i uniżeniem, „Gazeta Wyborcza”, 20.01.2001.

42 Ibidem.
} 
ujęć ${ }^{43}$ i pozbawił swój film wszystkich charakterystycznych dla japońskiej estetyki elementów scenografii (rozpoznawalnych jako typowo japońskie). Jednak ta transparentna kulturowo przestrzeń i częste stosowanie bliskich planów silniej jeszcze akcentują obecność „obcej”. Wśród charakterystycznych i wyrazistych azjatyckich twarzy, zdecydowanie wyróżnia się jasnowłosa i jasnooka Amélie (w tej roli Sylvie Testud). Amelie, co należy podkreślić, nie jest jedyną kobietą w firmie. Jej bezpośrednim zwierzchnikiem jest również kobieta. Książka Nothomb i film Corneau otwierają się bardzo zdecydowanie na problematykę, która w dokumencie Jiro śni o sushi została jedynie zasugerowana przez niemal zupełny brak kobiet w historii ukazanej przez Gelba. W Bojaźni i drżeniu kobiety są, co więcej - pracują. Mariusz Cieślik, komentując utwór Nothomb, pisze:

\begin{abstract}
Mówiąc najprościej: ( ... życie kobiety w Japonii jest koszmarem. Przynajmniej z naszego europejskiego punktu widzenia. Jednak Japonki, co widać w książce Nothomb, zdają sobie doskonale sprawę z tego, w jakim żyją upodleniu. Jeśli zaufać wiedzy autorki $Z$ pokora $i$ uniżeniem „Pozostawanie przy życiu jest z jej (Japonki - przyp. M.C.) strony szczytnym i bezinteresownym przejawem oporu i odwagi”. Kobiety w Japonii żyją w niezwykle ciasnym gorsecie. Mają niemal wyłącznie obowiązki i niemal żadnych praw. Są pod nadzorem przez całe życie i w każdej sytuacji. Nie wolno im głośno sikać w toalecie. Nie wolno im się nawet pocić. To może je na całe życie okryć hańbą. Muszą też spełnić dwa najważniejsze, a przy tym sprzeczne ze sobą wymagania. Po pierwsze - wyjść za mąż do 25. roku życia, bo dłuższe pozostawanie w panieństwie oznacza „utratę twarzy”. Po drugie - muszą jak najwięcej pracować dla firmy, bo „dla Japończyka nigdy nie pracuje się zbyt wiele". Jednak nieustanna praca dla firmy w zasadzie wyklucza jakiekolwiek życie osobiste. Tak zatem kobieta, która próbuje robić w Japonii karierę, skazana jest raczej na samotność. Bo kobiety nie są przecież przeznaczone do osiągania wielkich sukcesów zawodowych, choćby nawet lepiej sprawdzały się w pracy niż mężczyźni. To tylko „ograniczone europejskie umysty” kierują się „ohydnym pragmatyzmem”. Dla Japończyków najważniejsze jest przestrzeganie „firmowych” hierarchii i podziału obowiązków. Efekty pracy są na dalszym planie. Dlatego nawet niezwykle zdolna kobieta musi bardzo wiele przecierpieć, by przeskoczyć choć jeden szczebel kariery. Musi też pracować na taki rzadko spotykany sukces znacznie więcej niż mężczyzna na tym samym stanowisku. A to znaczy, że musi pracować bez przerwy. Japonki mają jednak pewien przywilej, bowiem jak mówi bohaterka książki: „niepracowanie w japońskiej firmie jest niewątpliwie celem samym w sobie”. A po zamążpójściu kobieta może zrezygnować z pracy. W świetle tego, czego dowiadujemy się z powieści Nothomb, jest to coś w rodzaju ułaskawienia ${ }^{44}$.
\end{abstract}

Fubuki Mori (w tej roli Kaori Tsuji) szefowa Amélie w sposób doskonały realizuje ten paradygmat zawodowej kariery kobiety w Japonii, której sukces wyznacza ciągła i bezwzględna walka. Nie da się bowiem ukryć, że filmową przestrzeń biura postrzegamy, jeśli nie jak pole bitwy, to przynajmniej jak ring, na którym Amélie od pierwszych chwil skazana jest na przegraną ${ }^{45}$. Film powtarza też pewien stereotyp: w niektórych sytuacjach kobiety są bardziej bezwzględne niż mężczyźni. Fubuki Mori bez wątpienia jest. Zwłaszcza w filmie jej bezwzględność, ale też niewątpliwa inteligencja, przeciwstawiona została gburowatości i zwykłej głupocie pana Omochi, dyrektora naczelnego. Europejska mentalność musi

\footnotetext{
${ }^{43}$ Zob. S. Kołos, op. cit., s. 322-324.

${ }^{44}$ M. Cieślik, op. cit.

45 Por. E. Gonzalez, op. cit.
} 
więc skapitulować przed japońską, przynajmniej w Japonii. Dlaczego? Dlatego, że problem kulturowej odmienności - na co zwraca uwagę Ed Gonzalez - ma swoje źródło także w uwarunkowaniach historycznych ${ }^{46}$. Amélie jest jego zdaniem symbolem współczesności, a feudalna struktura japońskiej korporacji, postrzegana przez Europejczyków jako relikt przeszłości, to przestrzeń, gdzie przeszłość (tradycja) styka się z teraźniejszością i nadal jest celebrowana jako najważniejszy fundament japońskiego społeczeństwa. Mówiąc za Gonzalezem - Amélie jest z innych czasów niż jej japońscy współpracownicy. Jedyne więc, co bohaterka filmu może zrobić, to nauczyć się - wzorem Japończyków - pokory, by przetrwać.

Historia Amélie dowodzi (częstej) nieprzydatności badawczych metodologii w prawdziwym procesie adaptacyjnym w nowej kulturze. Relatywizm kulturowy ${ }^{47}$ będący podstawową metodą poznawczą dla antropologów, nie sprawdza się jako życiowa dyrektywa dla „obcego” w nowej kulturowej rzeczywistości ${ }^{48}$. Jak pisze Cieślik:

Łatwo powiedzieć i postulować, a jak badacza poczęstują kawałkiem ludziny, to cóż ma począć? Mówiąc jednak najzupełniej poważnie: jako metoda badawcza relatywizm kulturowy położył ogromne zasługi dla rozwoju antropologii. Tyle że sama dyrektywa wyjścia poza normy własnej kultury jest oczywiście ideałem niemożliwym do osiągnięcia, a ponadto próba zbliżenia się do owego ideału może się czasem źle skończyć, na co dowodów dostarcza choćby książka Amelie Nothomb. Jej autorka-narratorka na własnej skórze doświadcza ułomności tej metody. Bo sama na sobie prowadzi badania ${ }^{49}$.

Europejskość bohaterki była elementem determinującym - i destrukcyjnym - jej zawodowego, japońskiego doświadczenia. Amélie Nothomb i Alain Corneau zdają się mówić: zawsze jesteśmy skądś. Nawet jeśli nie jesteśmy przywiązani (czy też przekonani) do definiowania własnej tożsamości przez pryzmat konkretnej kultury narodowej, to pewnością są sytuacje i miejsca, w których musimy stwierdzić, że zdecydowanie nie jesteśmy stąd.

\section{Jiro i Amélie - mentalność sfilmowana}

Sfilmowanie mentalności to rzecz niełatwa. Choć wielu reżyserów próbowało to zrobić, do tej pory sztuka ta udała się niewielu: Felliniemu, Bergmanowi, Allenowi. Corneau i Gelb też sprostali temu niełatwemu zadaniu, choć sfilmowali japońską mentalność w różny sposób. Corneau - dochowując wierności stylowi literackiego pierwowzoru - postawił na bezpośredniość i dosłowność opisu. Zdecydowanie i bez zastrzeżeń zawierzył sugestywnej relacji Amélie. Gelb szukał prawdy o japońskiej mentalności między poetyckimi obrazami przyrządzania sushi, realizmem scen z targu rybnego, a tym, czego nie widać - światem nieprzedstawionym swojej opowieści, który wydaje się równie ważny, jak to, co zostało utrwalone na taśmie filmowej. Swój sukces twórcy zawdzięczają fundamentalnej decyzji

46 Ibidem.

47 Relatywizm kulturowy - „dyrektywa metodologiczna zalecająca dostrzeganie swoistych cech badanej kultury, a nie widzenie jej przez pryzmat kultury, z której badacz się wywodzi" hasło na http://encyklopedia. pwn.pl/haslo/3966979/relatywizm-kulturowy.html [stan na dzień: 30.04.2013].

48 Zob. S. Kołos, op. cit., s. 324.

49 M. Cieślik, op. cit. 
- by skupić swoją analizę na jednym, najważniejszym aspekcie ich życia - pracy. Wpłynęła ona bezpośrednio na rozwiązania formalne, przede wszystkim na przestrzeń filmową. Choć przestrzenna dyscyplina, charakteryzuje przede wszystkim Bojaźń i drżenie, gdzie jednorodność przestrzeni zostaje przełamana tylko raz - w surrealistycznej scenie, gdy bohaterka wyobraża sobie, że wyskakuje przez okno - w Jiro śni o sushi jej kompozycja z pewnością nie jest dziełem przypadku, wszystko bowiem, co najistotniejsze, dzieje się w mikroskopijnej przestrzeni restauracji Jiro (jest w niej tylko dziewięć miejsc). Znaczenie scen na targu rybnym doceniamy dopiero pod koniec filmu, kiedy wiemy już, jaki udział w Michelinowskim sukcesie restauracji miał starszy syn głównego bohatera ${ }^{50}$. Takie rozwiązania wymagają od twórców filmowych maksymalnego skupienia na postaciach i sytuacjach. W obu filmach nie ma miejsc pustych dramaturgicznie i znaczeniowo. Kamera nie tylko pokazuje, ale też analizuje filmowane sytuacje i wypowiedzi, wyzyskując do analizy każdy szczegół i gest. Reżyserzy filmują ludzi w działaniu - bo ona najlepiej określa ich sposób myślenia. Słowo - choć towarzyszy nam w obu wypadkach w zasadzie cały czas - jest punktem wyjścia. Celem są utrwalone na obrazie ludzkie działania oraz skutki tych działań. Filmowcy zdają się mówić: to, co widzicie, ma swój początek w sposobie myślenia naszych bohaterów, którzy w tym wypadku myślą przede wszystkim o pracy.

Filmowe obrazy „pracy po japońsku” są w takim samym stopniu precyzyjnie skomponowane przez twórców, co subiektywne i znacząco różne. Tak jak różne były narracyjne punkty wyjścia obu historii i różne miejsca, o których opowiadali filmowcy. David Gelb, artysta i koneser ze Stanów Zjednoczonych, zafascynowany japońską kuchnią i efektami pracy swojego bohatera, chce, by także widzowi udzieliła się jego fascynacja. Alain Corneau natomiast oddaje głos narratorce, zdegustowanej pracą w japońskiej korporacji Belgijce, której opowieść sprawia, że zaczynamy bać się Japonii - przynajmniej jako miejsca pracy. I kiedy już nabierzemy przekonania, że nigdy nie chcielibyśmy być na miejscu Amélie, spytajmy samych siebie, czy widzimy siebie w roli uczniów Jiro? Pamiętając jednocześnie o tym, że terminowanie u mistrza trwa dziesięć lat, że byli tacy, który rezygnowali już po jednym dniu pracy. A co z kobietami - sushimasterami ${ }^{51}$ W Bojaźni i drżeniu jesteśmy wprost informowani o sytuacji kobiet zatrudnianych w korporacjach. W Jiro śni o sushi pewne fakty dotyczące prywatnej i zawodowej pozycji kobiet są jedynie sugerowane przez reżysera, mniej lub bardziej świadomie. „Lektura” obu filmów to bez wątpienia cenne doświadczenie. I bez względu na to, czy zgodzimy się czy nie z niepochlebną dla Japonii - mówiąc delikatnie - diagnozą Nothomb i Corneau, czy damy się uwieść obrazom Gelba, czy uznamy je za pretensjonalne i egzaltowane, dajmy artystom prawo powiedzieć o Japonii, co chcą i jak chcę - mają do tego prawo.

\footnotetext{
50 Od chwili, gdy Jiro miał zawał, na targ rybny chodzi tylko jego starszy syn - Yoshikazu.

51 "Jak zrobić odpowiednie nigiri? Ryż i ryba muszą mieć określoną wagę. Ryż nabieramy tak, aby całość zmieściła się w tej gramaturze. Liczy się sposób ugniatania ryżu oraz kształt, wszystko na raz musi zmieścić się w buzi. - Ni w japońskim oznacza rękę, giri ugniatać - tłumaczy Michał Jaworski. Ważna jest również temperatura ciała sushimastera. To podobno powód, dla któregos u s h i ni e mogą przygotow y wać k o b i e t y , bo mają... zbyt ciepłe dłonie. Takie przekonanie panuje przynajmniej w Japonii. Ryż w momencie podania powinien mieć temperaturę właściwą temperaturze ciała". Zob. Sushi - z czym to sięje?, http://kuchnia. wp.pl/mm/miszmasz/1402/1/1/sushi-z-czym-to-sie-je-.html [stan na dzień: 1.05.2013].
} 